\title{
Pharmaceutical Targeting the Envelope Protein of SARS-CoV-2: the Screening for Inhibitors in Approved Drugs
}

\author{
Anatoly Chernyshev \\ XR Pharmaceuticals Ltd., Cambridge, New Zealand \\ email: $\underline{a @ x p h . c o . n z}$
}

\begin{abstract}
An essential overview of the biological role of coronavirus viroporin (envelope protein) is given, together with the effect of its known inhibitors on the life cycle of coronavirus. A docking study is conducted using a set of known drugs approved worldwide ( $\mathrm{ca} .6000$ compounds) on a structure of the SARS-CoV-2 viroporin modelled from the published NMR-resolved structures. The screening has identified 36 promising drugs currently on the market, which could be proposed for pre-clinical trials.
\end{abstract}

\section{Introduction}

Viral ion channels (viroporins) are known since at least 1992, when the M2 channel of influenza A virus has been discovered. These ion channels exist in a form of homotetra- (e.g. the M2 channel) or homopentamers (e.g. coronavirus E channel); each subunit is 50-120 aminoacids long and has at least one transmembrane domain (TMD). The pore formed by the transmembrane domains of the oligomer acts as an ion channel. It is speculated that viroporins initiate a leakage in host cell membranes, which alters the tans-membrane potential and serves as a marker of viral infection [1]. SARS coronaviruses were found to have at least three types of ion channels: $\mathrm{E}$ and 8a (both with single TMD, forming pentameric assemblies), and 3a with three TMD [2, 3]. Both proteins E and 3a possess PDZ domainbinding motif (PBM). In the protein $\mathrm{E}$ it is the last four aminoacids in the C-terminus (DLLV, Table 1). The PBM of E protein was found to be directly involved in SARS-CoV pathogenesis by binding the host's syntenin protein resulting in overexpression of inflammatory cytokines contributing to the socalled "cytokine storm"[4]. Further to that, SARS-CoV E channel can be embedded into the ERGIC/Golgi membranes and facilitate $\mathrm{Ca}^{2+}$ transport resulting in the activation of the NLRP3 inflammasome followed by an overproduction of interleukin $1 \beta$ [5]. In the lifecycle of coronaviruses, $\mathrm{E}$ protein was found to be involved in morphogenesis and viral assembly, and was essential for the virus fitness $[6,7]$. This is evidenced by the experiment in which mutant SARS-CoV viruses with inactive $\mathrm{E}$ protein (caused by N15A or V25F mutation) were prone to revert the protein to its active state, both in cell culture and in infected mice. Lack of $E$ viroporin activity led to a significant reduction in pulmonary edema in mice, resulting in much lower mortality rates [8]. An exhaustive review of modern knowledge of molecular biology of coronavirus E proteins is given by Schoelman \& Fielding [9].

The E protein of both SARS-CoV and -CoV-2 is formed by 75-76 aminoacid residues, with three mutations and one insertion/deletion in the C-terminus (Table 1). The mutations are located far away from the targeted inhibitor binding site (N-terminus channel entrance and lumen), therefore they shall have no effect on the screening results.

The only available deposition for the E protein in the Protein Data Bank (PDB) is the NMR set of 16 structures of a truncated SARS-CoV channel in lyso-myristoyl phosphatidylglycerol micelles (PDB 5 X29 [10], see also Table 1 and Fig. 1). While these NMR models are lacking precision of X-ray structures, they offer several snapshots of the channel dynamics, which could be advantageous in the docking studies. It appears that the channel, and, specifically, its pore fluctuates wildly. Depicted on Fig. 2 are the lumen radii calculated with HOLE program [11]. The narrowest part of the channel could 
be $2.6-4.8 \AA$ wide, with an average of $4.4 \AA$. Fluctuations of similar magnitude are visible along the whole length of the channel.

Table 1. The sequences of E proteins from human SARS coronaviruses (as listed on uniprot.org [12]); the substructure of E protein, studied by NMR and deposited in Protein Data Bank (PDB); the modelled structure of E protein used for docking screening in this study. Blue - residues specific to SARS-CoV; red - residues specific to SARS-CoV-2; green - PBM [4, 13].

\begin{tabular}{|l|r|l|l|}
\hline & N-terminus & TMD & C-terminus \\
\hline $\begin{array}{l}\text { SARS-CoV } \\
\text { (Uniprot Q692E1) }\end{array}$ & MYSFVSEET & GTLIVNSVLLFLAFVVFLLVTLAILTAL & RLCAYCCNIVNVSLVKP T V YVYSRVKNLNSS EG VP DLLV \\
\hline $\begin{array}{l}\text { SARS-CoV, } \\
\text { truncated } \\
\text { (PDB 5X29 [10]) }\end{array}$ & ET & GTLIVNSVLLFLAFVVFLLVTLAILTAL & RLAAYAANIVNVSLVKP T V YVYSRVKNL \\
\hline $\begin{array}{l}\text { SARS-CoV-2 } \\
\text { (Uniprot P0DTC4) }\end{array}$ & MYSFVSEET & GTLIVNSVLLFLAFVVFLLVTLAILTAL & RLCAYCCNIVNVSLVKP S F YVYSRVKNLNSS R VP DLLV \\
\hline $\begin{array}{l}\text { SARS-CoV-2 } \\
\text { model used in } \\
\text { this study }\end{array}$ & EET & GTLIVNSVLLFLAFVVFLLVTLAILTAL & RLAAYAANIVNVSLVKP S F YVYSRVKNL \\
\hline
\end{tabular}
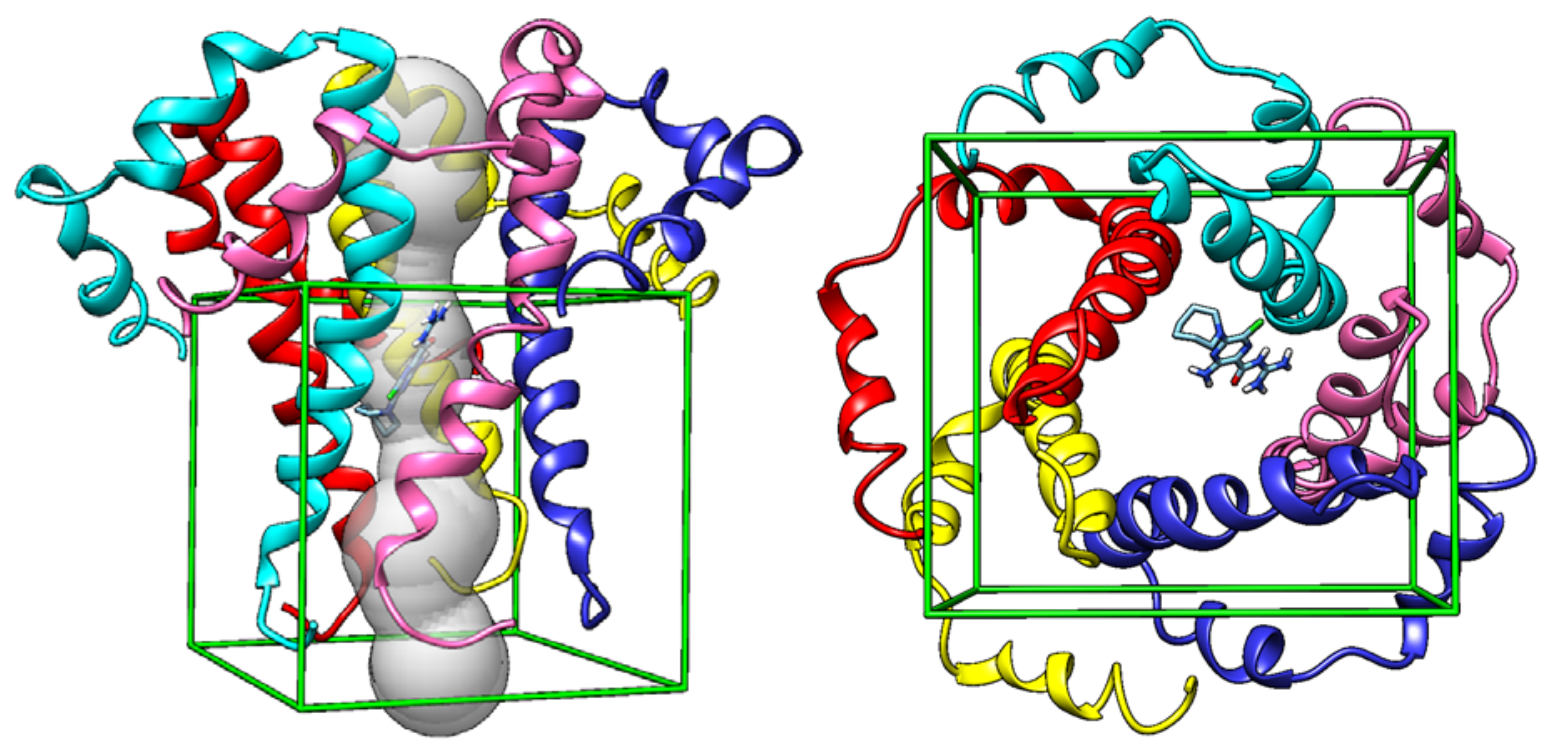

Figure 1. E protein pentamer of SARS-CoV-2 modelled from PDB 5X29 (Table 1). Left, side view with hexamethylene amiloride ligand in the pore (gray). Right, axial view from the N-terminus. Green cage, the docking site. 


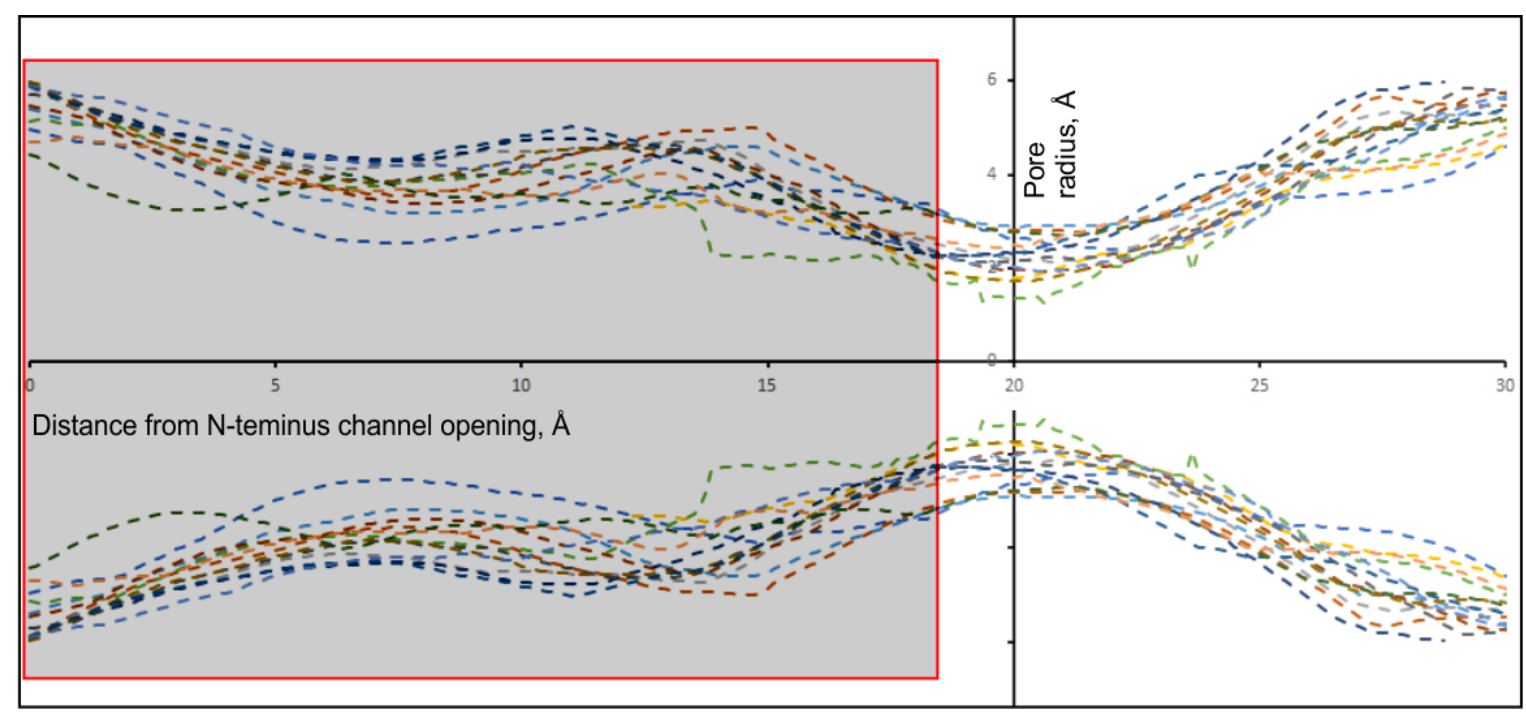

Figure 2. The geometry of channel's lumen, overlay of 14 NMR models of SARS-CoV E protein (from PDB 5X29 [10]). Shaded area — the zone used for docking.

Probably the most widely known drug acting as a viroporin blocker is amantadine (aminoadamantane), which has been in the medical practice to treat influenza since 1966, even before the viral ion channels were discovered. It blocks the M2 channel of influenza A virus and inhibits its replication [6]. The binding of amantadine to a synthetic TMD of E protein from SARS-CoV (sequence KKTGTLIVNSVLLFLAFVVFLLVTLAILTKK) was significant enough $\left(K_{\mathrm{d}} 7 \mathrm{mM}\right)$ to completely block the ion conductance [14].

Amiloride derivatives (in particular hexamethylene amiloride) were found to be efficient inhibitors of p7 channel of hepatitis $\mathrm{C}$ virus, and E proteins of coronavirus, with $K_{\mathrm{d}}$ of $\sim 10 \mu \mathrm{M}[6,15-17]$. These substances and amantadine feature a positively charged headgroup followed by a bulky hydrophobic scaffold, which might be the common structural feature of E-protein inhibitors:

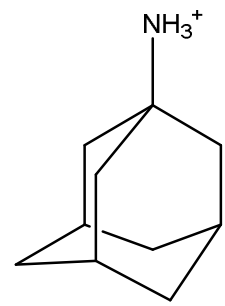

Amantadine

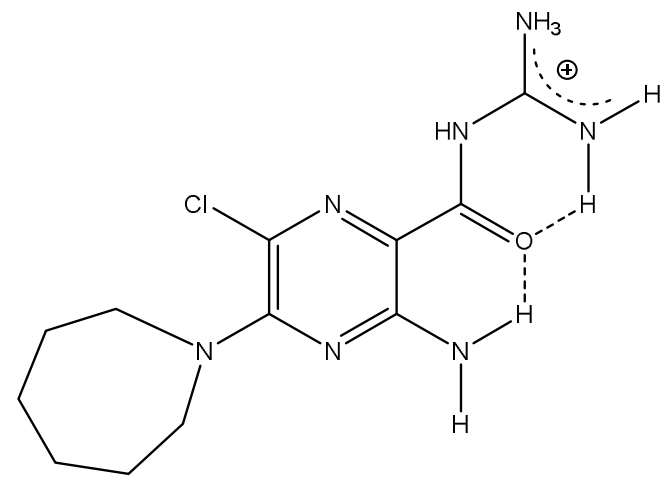

Hexamethylene amiloride, the active tautomer [18]

E protein is an unscrupulous ionic channel, which can conduct both anions and cations. The conductivity preference is dependent on $\mathrm{pH}$ and the lipid constituents of the membrane. In physiological conditions it appears to have slight preference for cations $\left(\mathrm{Na}^{+}, \mathrm{K}^{+}, \mathrm{Ca}^{2+}\right)[5,17]$. The simplest blocking mechanism would be if the cationic headgroup is dragged into the channel by the electric field, with the hydrophobic group following and plugging the entry for the succeeding ions.

Aside from the ability to block the E protein ionic channel, hexamethylene amiloride has been shown to actually supress the replication of coronaviruses (in particular, mouse hepatitis virus and HCoV-229E), as demonstrated by the plaque assay [16]. 
Since the ongoing COVID-19 pandemics requires urgent action, in this work we have conducted a docking screening study of drugs approved worldwide (approximately 6000 compounds, as deposited in the ZINC database [19]). The goal was to identify potential high affinity blockers of SARS-CoV-2 E channel, available on the pharmaceutical market, to recommend for further pre-clinical investigation.

\section{Computational details}

The 16 structures of truncated SARS-CoV-2 E protein channel were modelled from PDB 5X29 entity. In all chains of the deposited structure two amino acids were replaced and one added at the N-terminus (see Table 1) using Dunbrack rotamer library [20] as implemented in the UCSF Chimera package [21]. The N-terminus pore fragment up to the main constriction was chosen as the docking site (Fig. 1, 2).

The set of structures of drugs approved in major world jurisdictions ( $c a .6000$ total) was obtained from ZINC database [19]. A few other channel blockers (proven or potential) were added to this set: folic acid, tetrodotoxin, picrotoxane terpenoids [22].

The docking was conducted using AutoDock Vina [23] on a 96-core Linux instance from Amazon Web Services. The binding energy was estimated (by the order of magnitude) from the ratios between Vina scores of the ligand and hexamethylene amiloride $(\Delta \mathrm{G}=-29658 \mathrm{~J} / \mathrm{mole}$; Vina score $=-7 \mathrm{kcal} / \mathrm{mole})$ :

$$
K_{d}=\exp \left(\frac{-29658\left(\text { Vina }_{\text {ligand }} /-7\right)}{R T}\right)
$$

It has been found previously that AutoDock Vina docking performs well in the prediction of ligand binding energy for a given site provided there is a pre-calculated calibration between the Vina score $(\mathrm{kcal} / \mathrm{mole})$ and the experimental value for the binding energy for 6-10 ligands. This scheme produced results comparable to more elaborate methods, as tested in a docking challenge (www.drugdesigndata.org). For a beta-secretase enzyme, this algorithm gave results with root mean square error of $1.4 \mathrm{kcal} / \mathrm{mole}$.

Unfortunately, in the case of E channel, there are only two ligands with experimentally measured $K_{\mathrm{d}}$, so that the linear calibration clearly leads to an overestimated dissociation constants (e.g. for Vina score -10 it produces $K_{\mathrm{d}}$ in a picomolar range, which is too good to be true). On contrary, the equation above produces more realistic $K_{\mathrm{d}}$, in the range of $1-10 \mathrm{nM}$ for the top performing ligands.

For the screening purposes each drug structure was docked to 4 channel models (out of 16 available). Then the best Vina score was selected from all generated poses, and the drugs with the score of -10 and below were docked again on all 16 receptor structures. Despite the variability of the channel geometry (Fig. 2), the docking scores were surprisingly consistent, with the range not exceeding $3 \mathrm{kcal} / \mathrm{mole}$ on Vina score across the channel models.

Finally, the hits from the previous step were run through a pan-assay interference compounds (PAINS) filter to detect any substances with a potential to bind non-selectively to different proteins (https://www.cbligand.org/PAINS [24]). Only one compound, eltrombopag (Table 2), has been flagged on this step. However, its docking pose was appearing snugly inside the channel, as for other potential blockers.

\section{Results}

The final list (36 entries) of potential blockers is given in Table 2. Below we describe in more detail a few substances, which (subjectively) deserve special consideration. 


\section{i. $\quad$ Nocardamine and deferoxamine}

The best screening hit in this study was nocardamine (Vina score $-12.2 \mathrm{kcal} / \mathrm{mole}$ ), a siderophore first isolated as its ferric complex (known as ferrioxamine $\mathrm{E}$ [25]). It is a macrocycle fitting exactly the channel opening at the $\mathrm{N}$ terminus (Fig. 3). However, being a siderophore means binding $\mathrm{Fe}^{3+}$ ions with extremely high affinity $\left(K_{\mathrm{d}}\right.$ in the order of $\left.10^{-30} \mathrm{M}[26]\right)$. For practical purposes, this implies that in the cells these molecules will exist exclusively as their complexes, sequestering iron and other metals from the bodily liquids.

Further, there exist a non-cyclic relative of nocardamine, the approved drug deferoxamine (DrugBank ID $\underline{\text { DB00746): }}$

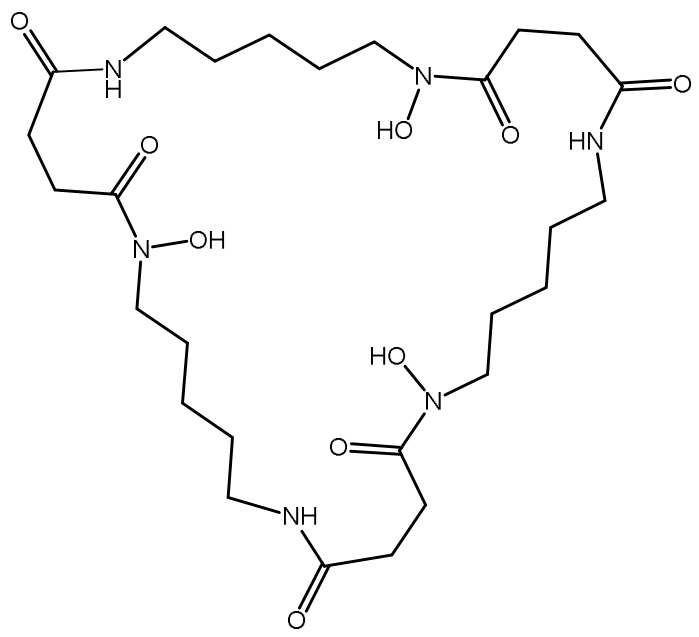

Nocardamine

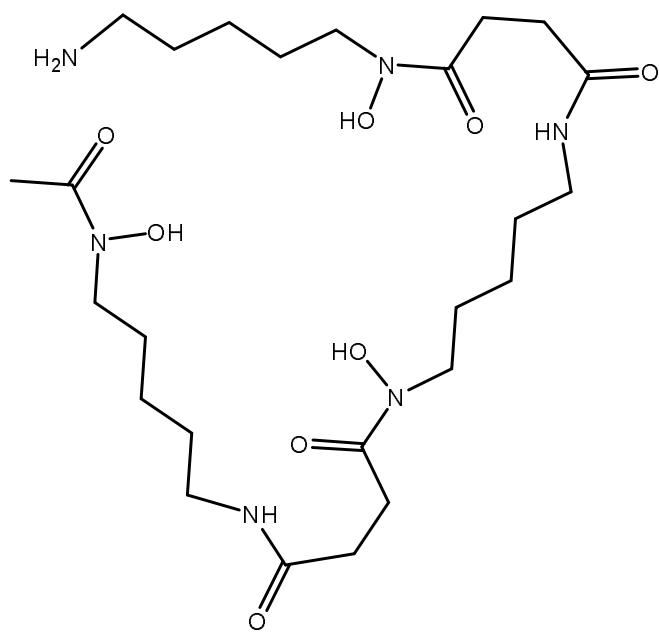

Deferoxamine

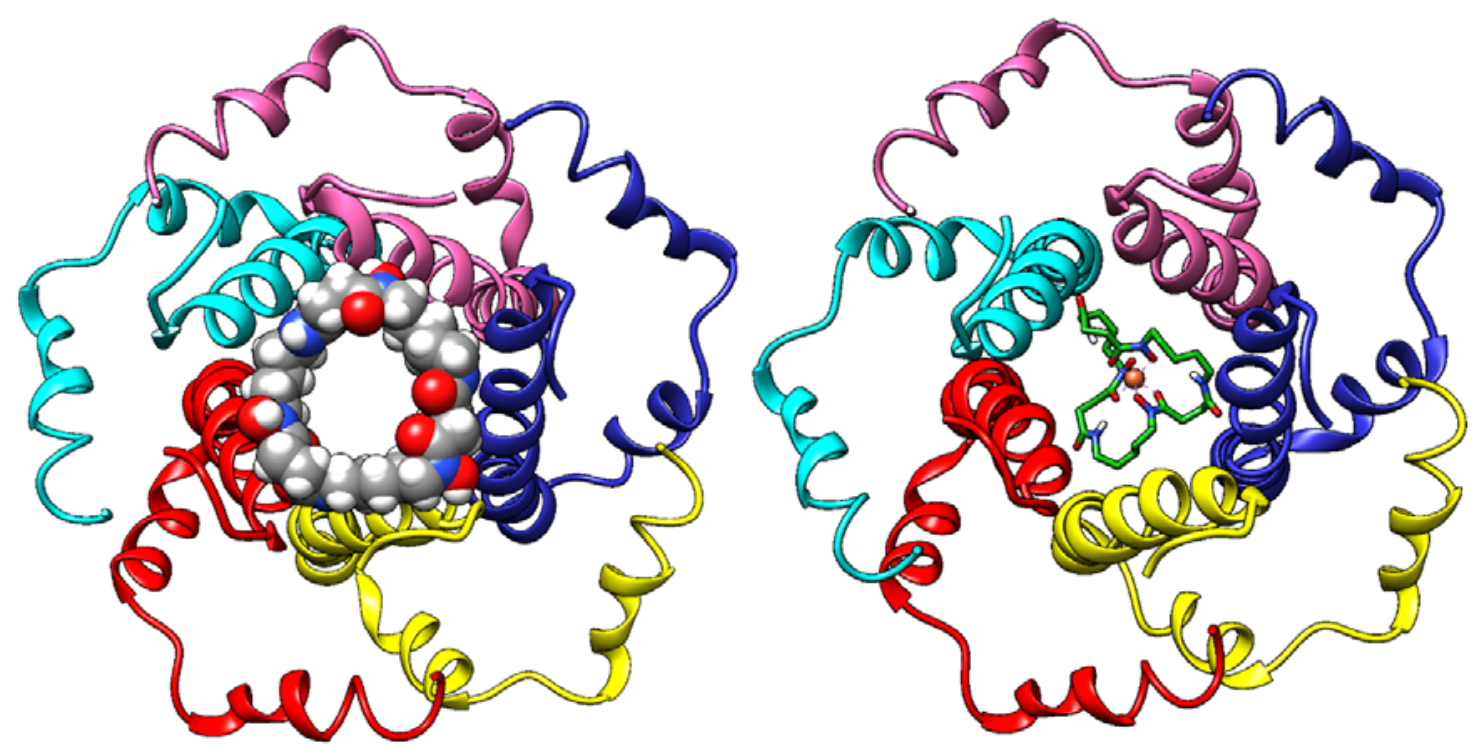

Figure 3. The docking poses of nocardamine (left), and its $\mathrm{Fe}^{3+}$ complex (right). 
It is prescribed specifically for this purpose - to remove excess of iron or aluminium from the body (e.g. to treat metal poisoning). In the screening it did demonstrate an unremarkable score of $-5.3 \mathrm{kcal} / \mathrm{mole}$. It was apparent that both compounds in physiological conditions will exist as metal complexes. Since the complexes shall have different geometry and chain flexibility, we have conducted a docking study on ferric complexes of both siderophores.

For the docking, deferoxamine- $\mathrm{Fe}^{3+}$ complex (known as desferrioxamine $\mathrm{B}$ ) was extracted from the $\mathrm{X}$ ray structure of its assembly with an acyl transferase (PDB 6ENK [27]). It has also served as a template to model the complex of nocardamine- $\mathrm{Fe}^{3+}$ (desferrioxamine $\mathrm{E}$ ).

The docking has revealed that both metal complexes shall bind with high affinity at the channel mouth effectively blocking it (Fig. 3, right). The lowest Vina score for desferrioxamine B was $-9.6 \mathrm{kcal} / \mathrm{mole}$ (much lower than for the bare ligand); for desferrioxamine $\mathrm{E}$ it was remarkable $-11.3 \mathrm{kcal} / \mathrm{mole}$, just a notch higher than for nocardamine alone.

\section{ii. $\quad$ Glycyrrhizic acid}

The major sweet constituent of liquorice (the root of Glycyrrhiza glabra), this is probably the cheapest, safest, and overall best-known compound from all screened hits. It has been used in vernacular practices throughout Asia for more than 4000 years. Today it is a food sweetener and a constituent of various food products.

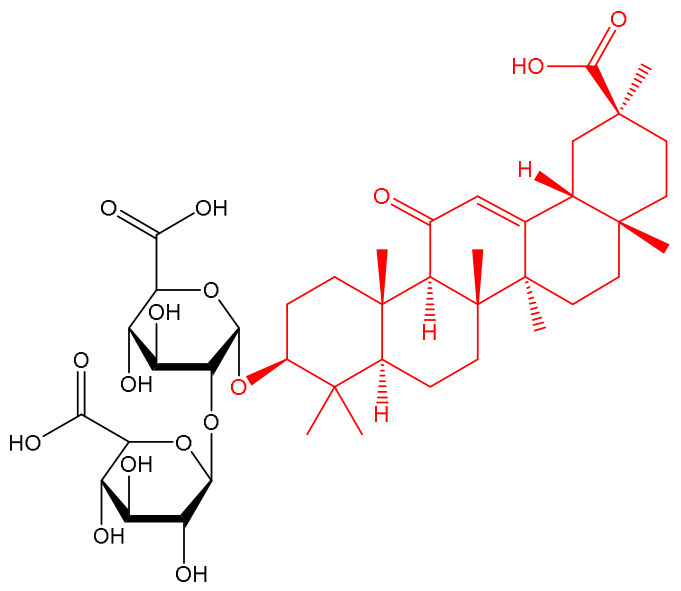

Glycyrrhizic acid (red is the aglycone, glycyrrhetic acid or enoxolone, DrugBank ID DB13089)

A broad spectrum of antiviral activity of this compound was discovered as early as the seventies. It interfered with life cycle of both DNA and RNA viruses, and irreversibly inactivated herpes virus [28, 29]. During the first SARS epidemy, it was demonstrated that glycyrrhizic acid did eliminate SARS$\mathrm{CoV}$ virus from infected monkey cells, although high doses $(0.3-2.4 \mathrm{~g} / \mathrm{L}$, final concentration) were required [30, 31].

Upon ingestion, glycyrrhizic acid is almost $100 \%$ hydrolysed down to its aglycone, glycyrrhetic acid (see above). The latter therefore is a bioavailable form for the body cells. In this regard we have separately docked the aglycone into the $\mathrm{E}$ channel. It did form a very similar docking pose as the original glycoside; the Vina score $(-10.2 \mathrm{kcal} / \mathrm{mole})$ was also very close to $-10.6 \mathrm{kcal} / \mathrm{mole}$ for the parent drug (Fig. 4). 


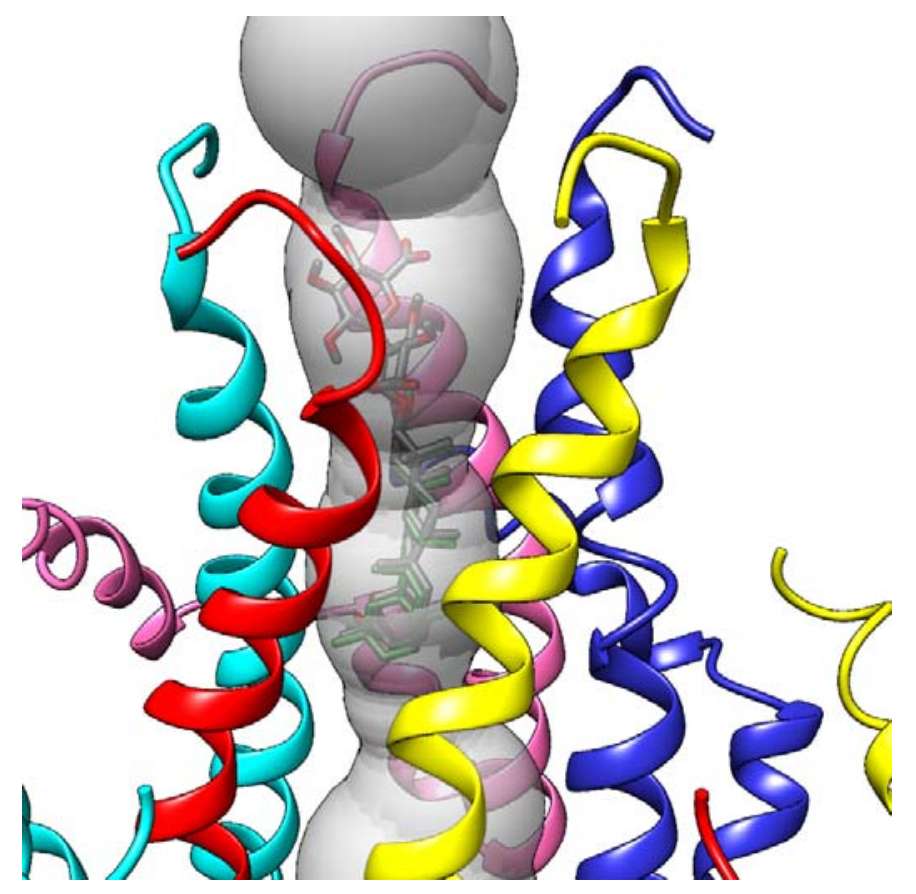

Figure 4. The overlay of docked poses for glycyrrhizic acid and its aglycone inside the E channel pore.

\section{iii. Cepharanthine}

Cepharanthine (Fig. 5) is a biscoclaurine alkaloid from Taiwanese plant Stephania cepharantha. It is approved in Japan since the fifties for the treatment of a truly wide range of medical conditions with no or little side effects (for a review see [32, 33]).

Of importance for this study is its antiviral activity. A significant part of it is due to the suppression of production of inflammatory cytokines and chemokines (quenching of the infamous "cytokine storm"). Cepharanthine has been shown to suppress HIV-1 virus replication due to inhibition of NFkB transcription factor, and reducing the cell membrane fluidity. Other viruses susceptible to cepharanthine treatment are hepatitis B, herpes, human T-lymphotropic virus, coxsackievirus, possibly ebola virus $[32,34]$.

Most importantly, it did show activity in vitro against the coronaviruses. Earlier it was found that in Vero E6 cells cepharanthine at $10 \mu \mathrm{g} / \mathrm{ml}$ completely inhibited SARS-CoV cytopathic effects [34]. In a recent similar experiment with SARS-CoV-2-related pangolin coronavirus, the replication was completely inhibited at $\sim 2 \mu \mathrm{g} / \mathrm{ml}$ of cepharanthine [35]. Another recent screening study [36] reports that cepharanthine severely reduces $\mathrm{N}$ protein expression of SARS-CoV-2, and completely inhibits the virus at $\sim 0.2 \mu \mathrm{g} / \mathrm{ml}$. This is in line with the report on the effect of cepharanthine on a common cold coronavirus (HCoV-OC43 [37]), where it suppressed both $\mathrm{N}$ and the spike protein expression. Also, the drug was effective on earlier stages of infection, indicating inhibition of the virus entry [35, 37]. The latter fact coincides with the results of our study, since viroporins were found to play a role in the virus entry too [2, 8]. However, docking results of the other study [36] showed that cepharanthine might also bind to the spike protein thereby interfering with its binding to the ACE2 receptor. In addition, cepharantine was also found to dock well with the non-structural proteins of SARS-CoV-2, NSP12NSP7-NSP8 complex [38]. 

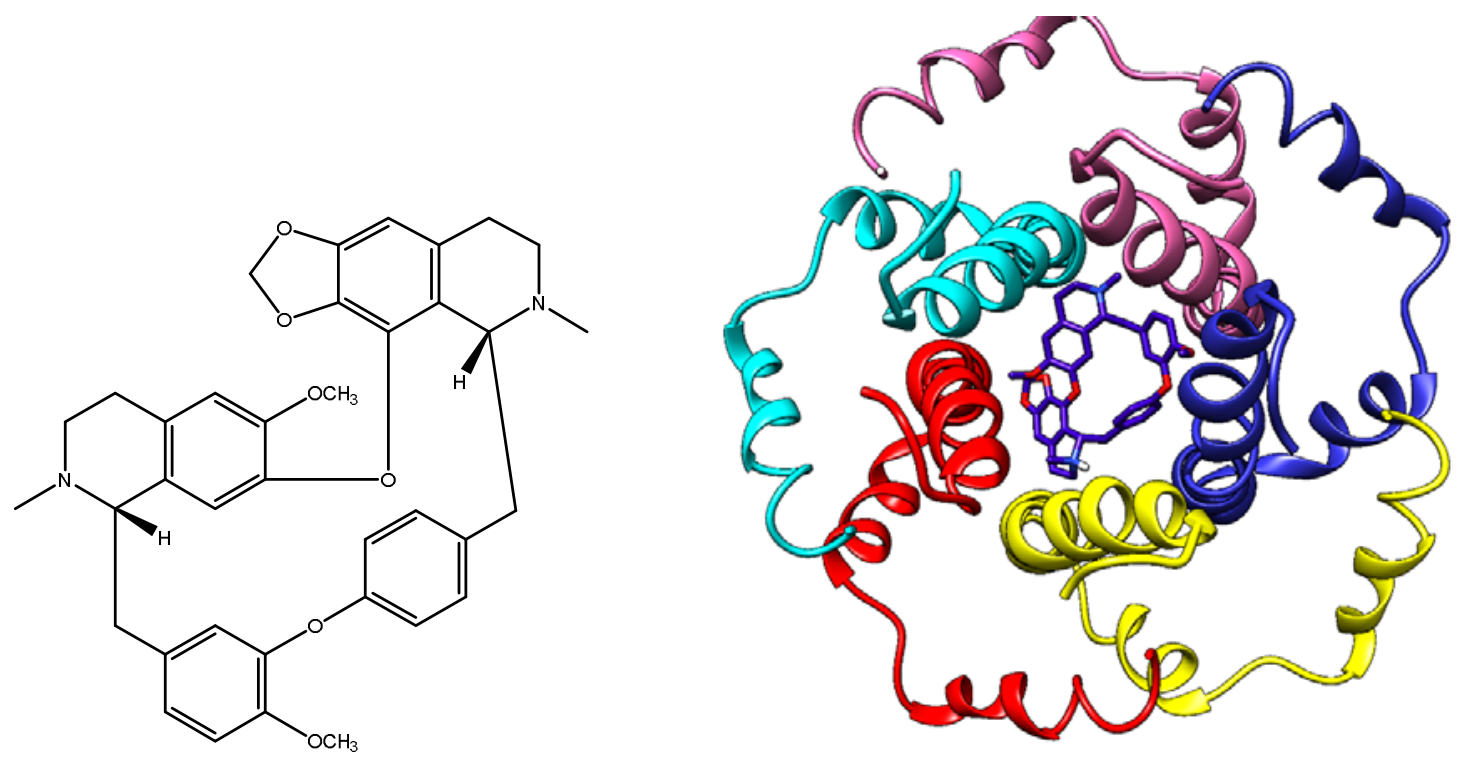

Figure 5. Cepharanthine structure and its docking pose.

\section{iv. Trypan blue}

Trypan blue (Fig. 6) is a diazo-dye, which has played a historical role in the discovery of the bloodbrain barrier. In 1913 Edwin Goldmann, a trainee of Paul Ehrlich, injected trypan blue into cerebrospinal fluid of laboratory animals, and found that the dye stained the brain only, but not the other organs. Alternatively, intravenous injections of the dye led to staining of the body tissues, but not the brain. In 1950 it has been clarified that the staining was due to the dye-protein complexes, which could not cross the barrier [39].

Today the dye is used for specific staining of dead cells in microscopy. In medicine it is used in ophthalmic cataract surgery to stain the anterior capsule. However, another historical role of Trypan blue (also under Ehrlich's supervision) is that it has been a prototype of effective drugs to treat human trypanosomiasis [40].

In our study Trypan blue did show a great affinity towards the E protein, and its pose was adequate for the channel blocking (Fig. 6). However, taking into account its unscrupulous binding to diverse proteins, it indicates that the active doses of the dye might be unacceptably high. 

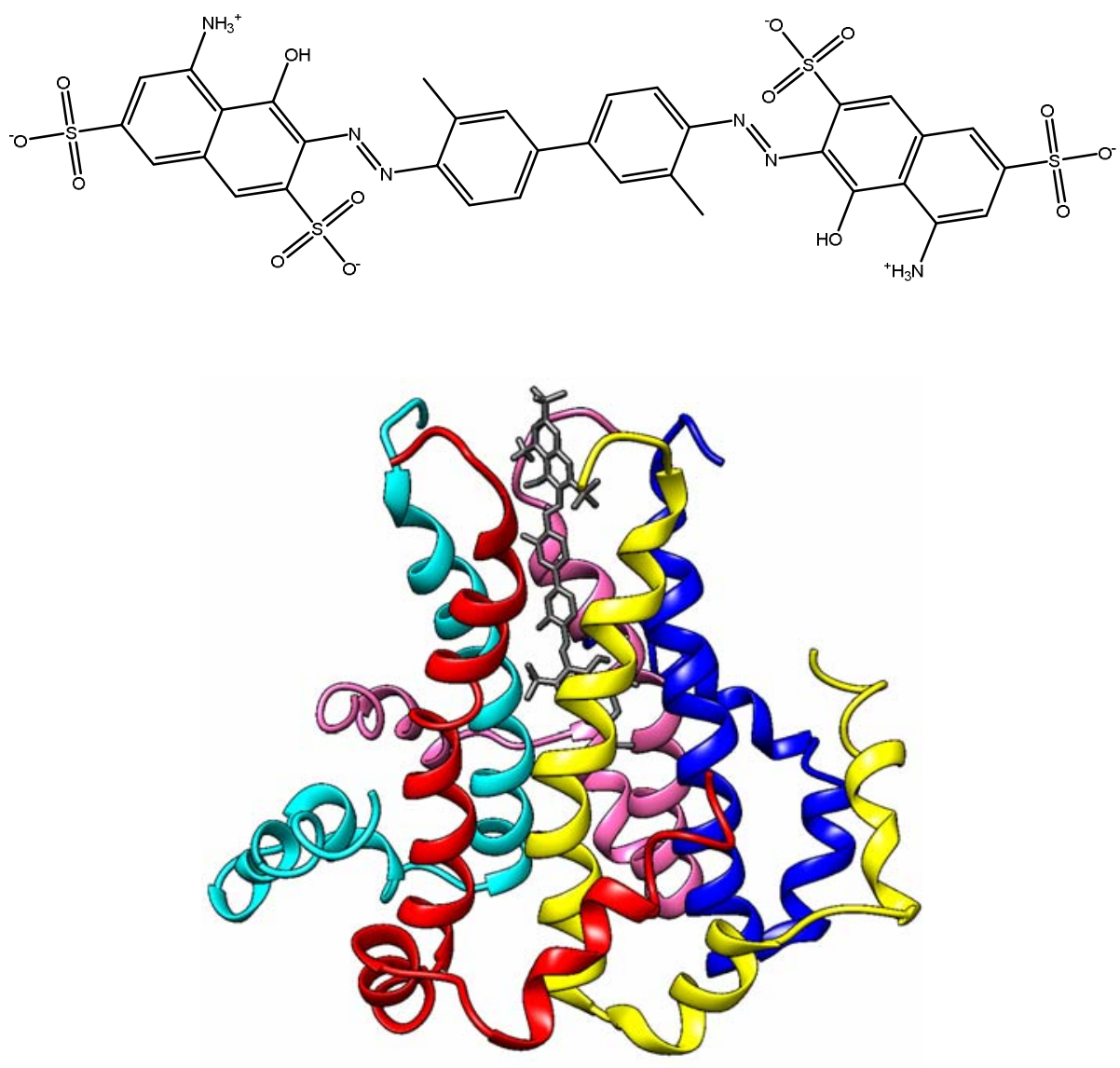

Figure 6. Trypan blue structure and its docking pose.

\section{Conclusions}

In this manuscript we have demonstrated the potential of the SARS-CoV-2 E protein as a pharmaceutical target. Our study complements earlier docking screening by Gupta et al. [41], where more than 4000 of phytochemicals were tried on the same protein and three of those were found promising (belachinal, macaflavanone E, vibsanol B).

We have found 36 approved drugs (Table 2), which potentially could block the channel and inhibit the virus life cycle. Some of those compounds could be ruled out from the consideration straight away due to safety concerns (e.g. the curare alkaloids, opiates, penfluridol). Some others (the three approved antivirals, glecaprevir, saquinavir, simeprevir) were mentioned more than once in the current theoretical and laboratory research related to Covid-19.

Remarkably, two of the hits (glycyrrhizic acid and cepharanthine) already have experimental data supporting their substantial activity against the SARS viruses.

The remaining drugs from the list could be recommended for further wet lab investigations.

Get well. 
Table 2. The screened list of potential blockers of SARS-CoV-2 E channel. Bold - entries detailed in the results section; red - entries failing the PAINS screen; WHO list - World Health Organisation list of essential medicines, https://list.essentialmeds.org; Drugbank — https://www.drugbank.ca; KEGG-D — KEGG Drug Database, https://www.kegg.jp/kegg/drug.

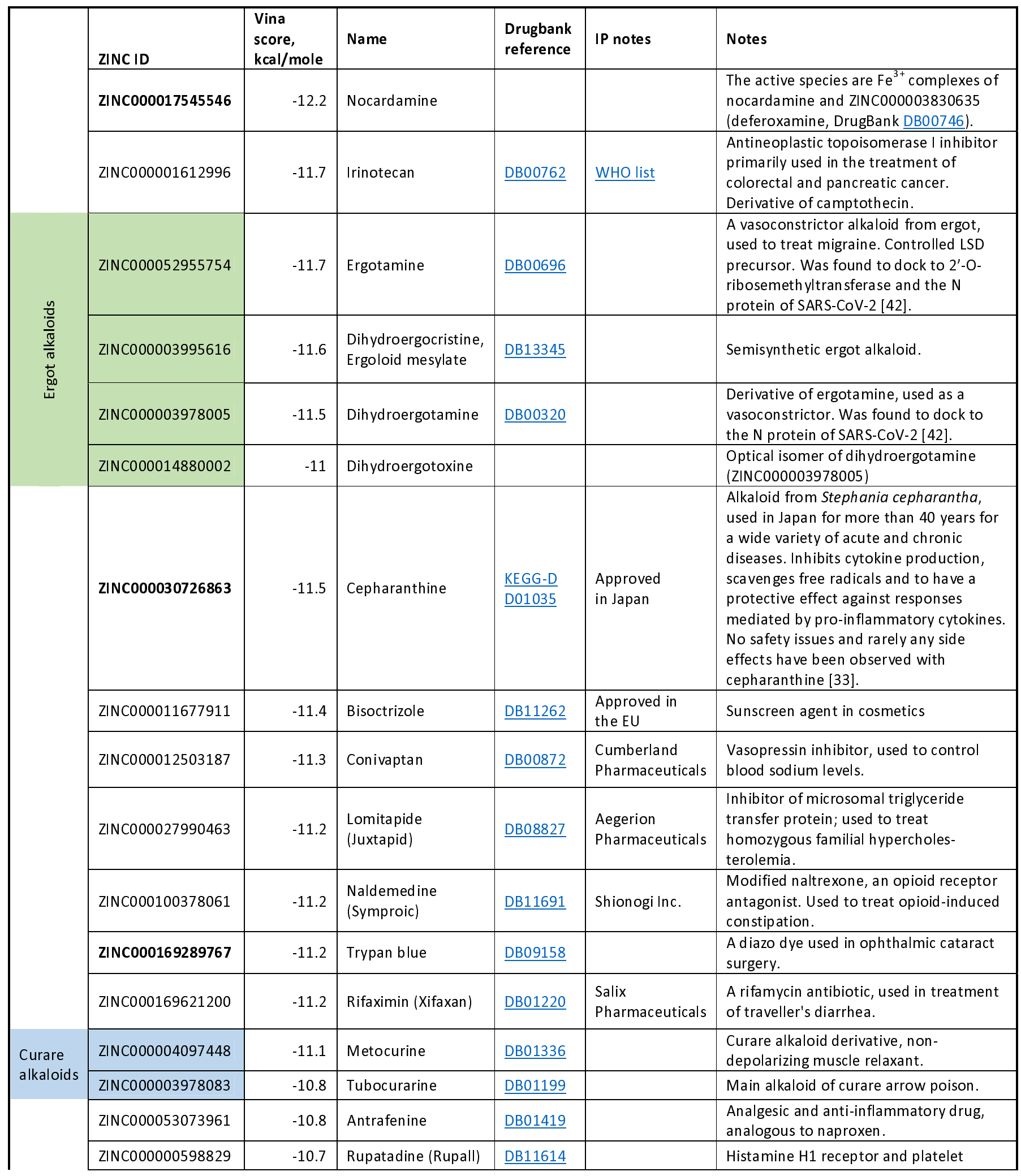




\begin{tabular}{|c|c|c|c|c|c|c|}
\hline & & & & & & $\begin{array}{l}\text { activating factor receptor antagonist; } \\
\text { used to treat rinitis and rash. }\end{array}$ \\
\hline & ZINC000011679756 & -10.7 & $\begin{array}{l}\text { Eltrombopag } \\
\text { (Promacta) }\end{array}$ & DB06210 & Novartis & $\begin{array}{l}\text { Thrombopoietin receptor agonist to treat } \\
\text { low platelet counts. Filtered out by the } \\
\text { PAINS screen [24]. }\end{array}$ \\
\hline & ZINC000001530886 & -10.6 & Telmisartan & $\underline{B D 00966}$ & & $\begin{array}{l}\text { Angioten sin II receptor antagonist for the } \\
\text { management of high blood pressure. }\end{array}$ \\
\hline & ZINC000096015174 & -10.6 & $\begin{array}{l}\text { Glycyrrhizic acid } \\
\text { and its aglycon }\end{array}$ & DB13751 & & $\begin{array}{l}\text { A diglycoside, the main sweet-tasting } \\
\text { constituent of Glycyrrhiza glabra } \\
\text { (liquorice) roor. The aglycon has Vina } \\
\text { score of }-10.2 \text {. }\end{array}$ \\
\hline & ZINC000299817032 & -10.6 & Moxidectin & $\underline{\text { DB11431 }}$ & $\begin{array}{l}\text { Medicines } \\
\text { Development } \\
\text { for Global } \\
\text { Health }\end{array}$ & $\begin{array}{l}\text { Wide spectrum antiparasitic drug, binds } \\
\text { to Glu-gated chloride ion channes, } \\
\text { similarly to ivermectin. }\end{array}$ \\
\hline & ZINC000019360739 & -10.4 & Flunarizine & DB04841 & & $\begin{array}{l}\text { Calcium transport inhibitor to treat } \\
\text { migraine. }\end{array}$ \\
\hline & ZINC000000577115 & -10.3 & Xaliproden & DB06393 & Sanofi & $\begin{array}{l}\text { 5-hydroxytryptamine } 1 \mathrm{~A} \text { receptor agonist } \\
\text { with neuroprotective activities. } \\
\text { Discontinued after Phase III trial. }\end{array}$ \\
\hline & ZINC000003925861 & -10.3 & $\begin{array}{l}\text { Vorapaxar } \\
\text { (Zontivity) }\end{array}$ & DB09030 & Merck & $\begin{array}{l}\text { Inhibits platelet aggregation through the } \\
\text { reversible antagonism of thrombin } \\
\text { receptor. Reduces thrombosis. }\end{array}$ \\
\hline & ZINC000006716957 & -10.3 & Nilotinib (Tasigna) & DB04868 & $\begin{array}{l}\text { Novartis; } \\
\text { WHO list }\end{array}$ & $\begin{array}{l}\text { Tyrosine kinase inhibitor for the } \\
\text { treatment of chronic myelogen ous } \\
\text { leukaemia. }\end{array}$ \\
\hline & ZINC000034608502 & -10.3 & Umeclidinium & DB09076 & $\begin{array}{l}\text { Glaxo Smith } \\
\text { Kline }\end{array}$ & $\begin{array}{l}\text { Muscarinic receptor ligand, used for the } \\
\text { treatment of chronic obstructive } \\
\text { pulmonary disease. }\end{array}$ \\
\hline & ZINC000100013130 & -10.3 & $\begin{array}{l}\text { Midostaurin } \\
\text { (Rydapt) }\end{array}$ & DB06595 & Novartis & $\begin{array}{l}\text { Multiple kinase inhibitor for the } \\
\text { treatment of acute myeloid leukemia. }\end{array}$ \\
\hline & ZINC000000601317 & -10.2 & Difenoxin & DB01501 & & Opioid controlled drug to treat diarrhea. \\
\hline Opioids & ZINC000003830716 & -10 & Diphenoxylate & DB01081 & & $\begin{array}{l}\text { Ethyl ether of difenoxin (above). Opioid } \\
\text { controlled drug to treat diarrhea. }\end{array}$ \\
\hline & ZINC000004217252 & -10 & Penfluridol & DB13791 & & $\begin{array}{l}\text { Antipsychotic with a very long lasting } \\
\text { action (elimination half-life } \sim 1 \text { week). }\end{array}$ \\
\hline & ZINC000100089496 & -10.2 & $\begin{array}{l}\text { Levocabastine } \\
\text { (Livostin) }\end{array}$ & $\underline{\mathrm{DB} 01106}$ & & $\begin{array}{l}\text { H1-receptor antagonist used for allergic } \\
\text { conjunctivitis. }\end{array}$ \\
\hline & ZINC000003934128 & -11 & $\begin{array}{l}\text { Temoporfin } \\
\text { (Foscan) }\end{array}$ & DB11630 & Biolitec Pharma & Porphyrin-based photosensitizing agent. \\
\hline & ZINC000003932831 & -10.8 & $\begin{array}{l}\text { Dutasteride } \\
\text { (Avodart) }\end{array}$ & DB01126 & & $\begin{array}{l}\text { Azasteroid } 5 \alpha \text {-reductase inhibitor; used } \\
\text { in the treatment of symptomatic benign } \\
\text { prostatic hyperplasia. }\end{array}$ \\
\hline & ZINC000936069565 & -11.8 & $\begin{array}{l}\text { Glecaprevir } \\
\text { (Mavyret) }\end{array}$ & $\underline{\text { DB13879 }}$ & AbbVie & $\begin{array}{l}\text { Direct inhibitor of NS3/4A protease of } \\
\text { hepatitis C virus, targeting the viral RNA } \\
\text { replication }\end{array}$ \\
\hline$\sum_{\substack{\frac{n}{\pi} \\
\frac{\pi}{4}}}^{\frac{n}{4}}$ & ZINC000026985532 & -10.7 & Saquinavir (Invirase) & $\underline{\text { DB01232 }}$ & $\begin{array}{l}\text { Hoffmann La } \\
\text { Roche, } \\
\text { Genentech }\end{array}$ & $\begin{array}{l}\text { HIV protease inhibitor to treat AIDS. Also } \\
\text { docks well to the NSP-complex of } \\
\text { SARS-CoV-2 [38]. }\end{array}$ \\
\hline & ZINC000253632968 & -11.3 & Simeprevir (Olysio) & DB06290 & & $\begin{array}{l}\text { Inhibitor for hepatitis C virus NS3/4A } \\
\text { protease. Also docks well to the NSP- } \\
\text { complex of SARS-CoV-2 [38]. }\end{array}$ \\
\hline
\end{tabular}




\section{References}

1. $\quad$ Fischer, W.B. and H.J. Hsu, Viral channel forming proteins - modeling the target. Biochim Biophys Acta, 2011. 1808(2): p. 561-71.

2. $\quad$ Castaño-Rodriguez, C., et al., Role of Severe Acute Respiratory Syndrome Coronavirus Viroporins E, 3a, and $8 a$ in Replication and Pathogenesis. mBio, 2018. 9(3): p. e2325-17.

3. Chen, C.-C., et al., ORF8a of SARS-CoV forms an ion channel: Experiments and molecular dynamics simulations. Biochimica et Biophysica Acta (BBA) - Biomembranes, 2011. 1808(2): p. 572-579.

4. Jimenez-Guardeño, J.M., et al., The PDZ-Binding Motif of Severe Acute Respiratory Syndrome Coronavirus Envelope Protein Is a Determinant of Viral Pathogenesis. PLOS Pathogens, 2014. 10(8): p. e1004320.

5. $\quad$ Nieto-Torres, J.L., et al., Severe acute respiratory syndrome coronavirus E protein transports calcium ions and activates the NLRP3 inflammasome. Virology, 2015. 485: p. 330-9.

6. Wang, K., S. Xie, and B. Sun, Viral proteins function as ion channels. Biochim Biophys Acta, 2011. 1808(2): p. 510-5.

7. $\quad \mathrm{Li}, \mathrm{S}$., et al., Regulation of the ER Stress Response by the Ion Channel Activity of the Infectious Bronchitis Coronavirus Envelope Protein Modulates Virion Release, Apoptosis, Viral Fitness, and Pathogenesis. Frontiers in Microbiology, 2020. 10(3022).

8. $\quad$ Nieto-Torres, J.L., et al., Severe Acute Respiratory Syndrome Coronavirus Envelope Protein Ion Channel Activity Promotes Virus Fitness and Pathogenesis. PLOS Pathogens, 2014. 10(5): p. e1004077.

9. Schoeman, D. and B.C. Fielding, Coronavirus envelope protein: current knowledge. Virology Journal, 2019. 16(1): p. 69.

10. Surya, W., Y. Li, and J. Torres, Structural model of the SARS coronavirus E channel in LMPG micelles. Biochim Biophys Acta Biomembr, 2018. 1860(6): p. 1309-1317.

11. Smart, O.S., et al., HOLE: A program for the analysis of the pore dimensions of ion channel structural models. Journal of Molecular Graphics, 1996. 14(6): p. 354-360.

12. The UniProt Consortium, UniProt: a worldwide hub of protein knowledge. Nucleic Acids Research, 2018. 47(D1): p. D506-D515.

13. Teoh, K.-T., et al., The SARS Coronavirus E Protein Interacts with PALS1 and Alters Tight Junction Formation and Epithelial Morphogenesis. Molecular Biology of the Cell, 2010. 21(22): p. 3838-3852.

14. Torres, J., et al., Conductance and amantadine binding of a pore formed by a lysine-flanked transmembrane domain of SARS coronavirus envelope protein. Protein science : a publication of the Protein Society, 2007. 16(9): p. 2065-2071.

15. Wilson, L., P. Gage, and G. Ewart, Validation of coronavirus E proteins ion channels as targets for antiviral drugs. Advances in experimental medicine and biology, 2006. 581: p. 573-578.

16. Wilson, L., P. Gage, and G. Ewart, Hexamethylene amiloride blocks E protein ion channels and inhibits coronavirus replication. Virology, 2006. 353(2): p. 294-306.

17. Pervushin, K., et al., Structure and inhibition of the SARS coronavirus envelope protein ion channel. PLoS Pathog, 2009. 5(7): p. e1000511.

18. Smith, R.L., et al., Proton, carbon-13, and nitrogen-15 nuclear magnetic resonance and CNDO/2 studies on the tautomerism and conformation of amiloride, a novel acylguanidine. Journal of the American Chemical Society, 1979. 101(1): p. 191-201.

19. Sterling, T. and J.J. Irwin, ZINC 15 - Ligand Discovery for Everyone. J. Chem. Information Modeling, 2015.55(11): p. 2324-2337.

20. Shapovalov, M.V. and R.L. Dunbrack, Jr., A smoothed backbone-dependent rotamer library for proteins derived from adaptive kernel density estimates and regressions. Structure, 2011. 19(6): p. 844-58.

21. Pettersen, E.F., et al., UCSF Chimera--a visualization system for exploratory research and analysis. J Comput Chem, 2004. 25(13): p. 1605-12.

22. Chernyshev, A., Of Tutu and Bugs. Chemistry in New Zealand, 2017. 81(1): p. 19-23. 
23. Trott, O. and A.J. Olson, AutoDock Vina: improving the speed and accuracy of docking with a new scoring function, efficient optimization, and multithreading. Journal of computational chemistry, 2010. 31(2): p. 455-461.

24. Baell, J.B. and G.A. Holloway, New Substructure Filters for Removal of Pan Assay Interference Compounds (PAINS) from Screening Libraries and for Their Exclusion in Bioassays. J. Med. Chem., 2010. 53(7): p. 2719-2740.

25. Korzybski, T., Z. Kowszyk-Gindifer, and W. Kuryłowicz, Antibiotics; origin, nature, and properties. 1967, New York: Pergamon Press.

26. Kiss, T. and E. Farkas, Metal-binding Ability of Desferrioxamine B. Journal of inclusion phenomena and molecular recognition in chemistry, 1998. 32(2): p. 385-403.

27. Ronan, J.L., et al., Desferrioxamine biosynthesis: diverse hydroxamate assembly by substratetolerant acyl transferase DesC. Philos Trans R Soc Lond B Biol Sci, 2018. 373(1748).

28. Pompei, R., et al., Glycyrrhizic acid inhibits virus growth and inactivates virus particles. Nature, 1979. 281(5733): p. 689-90.

29. Li, J.Y., et al., Glycyrrhizic acid in the treatment of liver diseases: literature review. Biomed Res Int, 2014. 2014: p. 872139.

30. Cinatl, J., et al., Glycyrrhizin, an active component of liquorice roots, and replication of SARSassociated coronavirus. The Lancet, 2003. 361(9374): p. 2045-2046.

31. Pilcher, H., Liquorice may tackle SARS. Nature, 2003.

32. Bailly, C., Cepharanthine: An update of its mode of action, pharmacological properties and medical applications. Phytomedicine, 2019. 62: p. 152956.

33. Rogosnitzky, M. and R. Danks, Therapeutic potential of the biscoclaurine alkaloid, cepharanthine, for a range of clinical conditions. Pharmacol Rep, 2011. 63(2): p. 337-47.

34. Zhang, C.H., et al., Antiviral activity of cepharanthine against severe acute respiratory syndrome coronavirus in vitro. Chin Med J (Engl), 2005. 118(6): p. 493-6.

35. Fan, H.H., et al., Repurposing of clinically approved drugs for treatment of coronavirus disease 2019 in a 2019-novel coronavirus-related coronavirus model. Chin Med J (Engl), 2020. 133(9): p. 1051-1056.

36. Ohashi, H., et al., Multidrug treatment with nelfinavir and cepharanthine against COVID-19. bioRxiv, 2020: p. 2020.04.14.039925.

37. Kim, D.E., et al., Natural Bis-Benzylisoquinoline Alkaloids-Tetrandrine, Fangchinoline, and Cepharanthine, Inhibit Human Coronavirus OC43 Infection of MRC-5 Human Lung Cells. Biomolecules, 2019.9(11).

38. Ruan, Z., et al., Potential Inhibitors Targeting RNA-Dependent RNA Polymerase Activity (NSP12) of SARS-CoV-2. 2020, Preprints.org, doi: 10.20944/preprints202003.0024.v1.

39. Dorovini-Zis, K. and S. Nag, Morphological and Functional Properties of the Blood-Brain Barrier, in The Blood-Brain Barrier in Health and Disease, K. Dorovini-Zis, Editor. 2015, CRC Press. p. 1-50.

40. Wainwright, M., Dyes, trypanosomiasis and DNA: a historical and critical review. Biotechnic \& Histochemistry, 2010. 85(6): p. 341-354.

41. Gupta, M.K., et al., In-silico approaches to detect inhibitors of the human severe acute respiratory syndrome coronavirus envelope protein ion channel. Journal of Biomolecular Structure and Dynamics, 2020: p. 1-11.

42. Kadioglu, O., et al., Identification of novel compounds against three targets of SARS CoV-2 coronavirus by combined virtual screening and supervised machine learning. Bull. World Health Org. doi: 10.2471/BLT.20.255943, 2020. 